\title{
STUDIES OF THE CHEMISTRY OF PERNICIOUS ANEMIA *
}

\author{
MAX KAHN, M.D., Ph.D., AND JOSEPH BARSKY, M.D. \\ NEW YORK
}

Squier ${ }^{1}$ has written an interesting and comprehensive review of the literature on the chemistry of pernicious anemia. Though a number of researches have been made on the pathochemistry of this very fatal disease, its causative factor is still unknown. Whether it is essentially a disease of the gastro-intestinal tract, with atrophy of the gastric mucosa and the absorption either of enterogenous poisons or protein split products, or whether it is a disturbance due to the hemolytic action of toxins elaborated in disease processes, or whether the disease is caused by hypersplenism, are the three main hypotheses in this mooted question.

The evidence brought forward by those authors who favor one or the other of these theories is not conclusive. A large number of chemical substances, such as oleic acid, saponins, phenylhydrazin, b-amino-azolyl-ethyl benzaldehyd, p-oxyphenylethylamin, etc., are violent hemolytic agents, and experimentally such poisons will produce anemia and hemoglobinuria, etc., but no definite proofs have been advanced that such substances are actually present in the idiopathic anemias. Iwao has been able to isolate p-oxyphenylethylamin from autolyzing pancreas, putrefying horse flesh and Swiss cheese. It is quite evident that this base may normally arise in the intestine from putrefying food, and it has been demonstrated by Berthelot and Bertrand $^{2}$ that there is an organism in the intestine- $-B$. aminophiluswhich can produce p-oxyphenylethylamin from tyrosin. Barger and $\mathrm{Dale}^{3}$ have isolated another hemolytic amin, b-imino-azolylethylamin, from the mucosa of the small intestine of the ox. Grawitz ${ }^{4}$ assumed that intestinal stasis was a great cause in the production of pernicious anemia, due to the absorption of poisons from the decay of food in the alimentary canal. Berger and Tsuchiya ${ }^{5}$ found that extracts obtained from the mucosa of the intestines of anemic animals have a much stronger hemolytic power than extracts from the mucosa of normal animals. This has, however, been controverted by Ewald and Friedberger.

* From the Department of Laboratories, Beth Israel Hospital.

1. For complete bibliography see Squier, T. L.: J. Lab. \& Clin. Med. 2: No. 8, 1917.

2. Berthelot and Bertrand: Compt. rend. Acad. Sc. 154:1463, 1912.

3. Barger and Dale: J. Physiol. 61:499, 1911.

4. Grawitz: Berl. klin. Wchnschr., 1898, pp. 704, 730.

5. Berger and Tsuchiya: Arch. f. klin. Med. 94:252, 1908. 
McPhedran found that the hemolytic power of organ extracts of cases of pernicious anemia fell entirely within normal limits, and gave no evidence of the presence of hemolytic toxins supposed to be the causative factor of the disease. That the lipin metabolism may be disturbed in the idiopathic anemias has been surmised by a number of authors. Kinnicutt reports two cases of pernicious anemia, which at necropsy showed lipoidosis of the adrenal cortex. This was indirectly and directly confirmed by the investigations of Hueck ${ }^{6}$ and of Landau.

It has been thought by Moffitt that hypersplenism as a cause of this disease may be brought about by toxins which reach the spleen through the main splenic arterial blood supply. "Erythrolysis does not take place in the spleen, but in some way the erythrocytes are sensitized and prepared for later destruction in the liver, marrow or lymph glands."

Examination of the Blood. - The bloods of three patients suffering from pernicious anemia were examined for certain constituents, and the results recorded (Table 1 ). We shall discuss several of the items individually. We have confirmed the findings of Ruttan and Adami (1896) that the specific gravity of the blood serum is lowered, that the total serum protein is much reduced-about 30 to $40 \mathrm{per}$ cent.-and that the ash was somewhat increased. The calcium in the blood was above normal. The glucose and cholesterol of the blood were normal as well as the total fat conient. In this regard we cannot corroborate King's results who found a high blood fat content and a reduced cholesterol content in cases of pernicious anemia.

Stidy of the Functional Capacity of the Gastro-Intestinal Tract.The method suggested by Rehfuss for the fractional analysis of the gastric contents was applied, the residuum removed and examined, with the results marked in Table 2 . The patients had fasted sixteen hours, from 6 p. m. to 10 a. m.

The residua seem to show a gastric stasis. According to Rehfuss, Bergeim and Hawk the volume of the normal average residuum is about 50 c.c., and shows a total acidity of about 30 and a free acidity of 18.5. In these cases the total acidity averaged 51, whereas the free acid was 0 . It may be stated that no pepsin hydrochloric acid was found in the cases of pernicious anemia, while tryptic digestion was present showing a regurgitation of the duodenal contents. The removal of the samples of gastric contents after an Ewald test meal yielded the results in Table 3 .

6. Hueck: See Squier, Footnote 1. 
Table 1.-Blood Axalysis in Cases of Pernicious Anemia

\begin{tabular}{|c|c|c|c|}
\hline & Case 1 & Case 2 & Case 3 \\
\hline Specific gravity of serum $\ldots \ldots \ldots \ldots \ldots \ldots \ldots$ & 1.0272 & 1.0963 & 1.0259 \\
\hline Water content of blood, parts per thousand...... & 856.12 & $8 \pm 3.27$ & 839.75 \\
\hline Dry matter of blood, parts per thousand......... & 143.88 & 156.73 & 160.25 \\
\hline Proteins of serum, parts per thousand............. & 5.915 & 5.217 & 5.337 \\
\hline Fat, parts per thousand $\ldots \ldots \ldots \ldots \ldots \ldots \ldots \ldots$ & 5.05 & 4.2 & 4.4 \\
\hline Cholesterol, mg. per 100 c.e. blood................ & 135.0 & 164.0 & 155.0 \\
\hline Nonprotein nitrogen, mg. per 100 c.c. blood........ & 38.5 & 29.3 & 30.2 \\
\hline Urea nitrogen, mg. per 100 c.c. blood............. & 20.1 & 18.4 & 19.7 \\
\hline Creatinin, mg. per 100 c.e. blood.............. & 2.8 & 4.8 & 5.4 \\
\hline 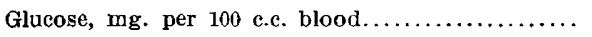 & 0.11 & 0.08 & 0.09 \\
\hline Uric acid, mg. per 100 c.e. blood. . . . . . . . . . . & 2.2 & 1.7 & 3.1 \\
\hline Carbon dioxid, parts per thousand.............. & 40.0 & 45.0 & 38.0 \\
\hline Ash, parts per thousand $\ldots \ldots \ldots \ldots \ldots \ldots \ldots \ldots$ & 0.77 & 0.82 & 0.85 \\
\hline Calcium oxid, parts per thousand.............. & 0.06 & $0.08 i$ & 0.092 \\
\hline Hydrogen-ion concentration ${ }^{*}\left(\mathbf{P}_{\mathrm{H}}\right) \ldots \ldots \ldots \ldots \ldots$ & 7.2 & 7.3 & 7.25 \\
\hline
\end{tabular}

* Oxalited blood.

TABLE 2.-ANalysis of Gastric Residicm

\begin{tabular}{c|c|c|c|c|c|c}
\hline Case & Volume, C.c. & Total Acid & Free Acid & Pepsin HCl & Trypsin & Bile \\
\hline 1 & 75 & 48 & 0 & - & + & Present \\
2 & 58 & 65 & 0 & - & + & - \\
3 & 64 & 40 & 0 & $?$ & + & - \\
\hline
\end{tabular}

The gastric curves produced by these cases of pernicious anemia strikingly resemble the curves of carcinoma of the stomach. The free acid is absent and the total acid varies between 15 and 45 . No blood was present; a trace of lactic acid was found in Case 2 ; pepsin was absent. The gastric mucosa appears to be altogether nonfunctionating, due to the complete atrophy that is doubtless present of the mucous membrane. The patients (Cases 1 and 2) were complaining of gastric distress, belching and anorexia, and they stated that they felt better when a solution of hydrochloric acid and pepsin was administered to them.

A roentgenogram of the gastro-intestinal tract did not reveal any abnormalities.

The Gastro-albumorrhea test, as devised by Salomon and as modified by Wolff and Junghans, was applied in Cases 2 and 3. The total nitrogen in 100 c.c. of gastric contents was $4.1 \mathrm{mg}$. (Case 2) and 
$3.7 \mathrm{mg}$. (Case 3). No albumin was present as determined by the phosphotungstic acid precipitation method. It is to be assumed that there is no discharge of protein from the gastric mucosa, although there no doubt is a chronic inflammatory process, in quantities sufficient to be tested.

The intestinal digestion was then investigated by the method of Schmidt and Strassburger. The patients were put on the test diet for three days, and the feces, the daily amounts being marked off by carmin, were collected and examined.

TABLE 3.-Fractional Analysis of Gastric Contents

\begin{tabular}{|c|c|c|c|c|c|c|}
\hline \multirow{2}{*}{$\begin{array}{l}\text { Time, } \\
\text { Minutes }\end{array}$} & \multicolumn{2}{|c|}{ Case 1} & \multicolumn{2}{|c|}{ Case 2} & \multicolumn{2}{|c|}{ Case 3} \\
\hline & Free Acid & Total Acid & Free Acid & Total Acid & Free Acid & Total Acic \\
\hline 15 & 0 & 36 & 0 & 22 & 0 & 14 \\
\hline 30 & 0 & 28 & 0 & 24 & 0 & 20 \\
\hline 45 & 0 & 40 & 0 & 35 & 0 & 25 \\
\hline 60 & 0 & 26 & 0 & 40 & 0 & 30 \\
\hline 75 & 0 & 30 & 0 & 45 & 0 & 32 \\
\hline 90 & 0 & 52 & 0 & 45 & 0 & 32 \\
\hline 105 & 0 & 56 & 0 & 50 & 0 & 36 \\
\hline 120 & 0 & 32 & 0 & 52 & 0 & 38 \\
\hline 135 & 0 & 36 & 0 & 50 & 0 & 40 \\
\hline 150 & 0 & 36 & 0 & 48 & 0 & 44 \\
\hline Blood............. & \multicolumn{2}{|c|}{-} & \multicolumn{2}{|c|}{ 一 } & \multicolumn{2}{|c|}{-} \\
\hline Lactic acid........ & \multicolumn{2}{|c|}{ - } & \multicolumn{2}{|c|}{ Trace } & \multicolumn{2}{|c|}{-} \\
\hline Bile.............. & \multicolumn{2}{|c|}{-} & \multicolumn{2}{|c|}{-} & \multicolumn{2}{|c|}{-} \\
\hline Mucus............ & \multicolumn{2}{|c|}{ Normal } & \multicolumn{2}{|c|}{ Mueh } & \multicolumn{2}{|c|}{ Moderate } \\
\hline Food.............. & \multicolumn{2}{|c|}{ Poorly digested } & \multicolumn{2}{|c|}{ Poorly digested } & \multicolumn{2}{|c|}{ Poorly digested } \\
\hline Pepsin ........... & \multicolumn{2}{|c|}{-} & \multicolumn{2}{|c|}{-} & \multicolumn{2}{|r|}{$?$} \\
\hline
\end{tabular}

In a series of six healthy individuals placed on this test diet for three days, Schmidt found the average weight of the dry feces to be $54.3 \mathrm{gm}$. The maximum was $62 \mathrm{gm}$. and the minimum was $45 \mathrm{gm}$. In a case of pancreatic disease, Pratt found the weight of the feces to be above $400 \mathrm{gm}$. The average weight of the dry feces in five cases of "fermentative dyspepsia," Schmidt found to be $127.4 \mathrm{gm}$.; the average weight in "gastrogenous diarrhea" with achylia was $98.9 \mathrm{gm}$.

The analyses of the feces in three cases of pernicious anemia are given in Table 4. 
TABle 4.-Analysis of Feces after Schmidt-Strassburger Test Diet

\begin{tabular}{|c|c|c|c|c|c|c|}
\hline \multirow{2}{*}{ Case } & \multirow{2}{*}{ Day } & \multirow{2}{*}{$\begin{array}{l}\text { Welght } \\
\text { Dry Feces, } \\
\text { Gm. }\end{array}$} & \multicolumn{2}{|c|}{ Total Nitrogen } & \multicolumn{2}{|c|}{ Fat } \\
\hline & & & Gm. & $\begin{array}{l}\text { Per Cent. of } \\
\text { Intake }\end{array}$ & Gm. & $\begin{array}{l}\text { Per Cent. of } \\
\text { Intake }\end{array}$ \\
\hline \multirow[t]{4}{*}{1} & 1 & 157.5 & 2.343 & 14.2 & 4.51 & 4.3 \\
\hline & 2 & 162.4 & 2.544 & 15.4 & 6.05 & 5.5 \\
\hline & 3 & 175.5 & 1.897 & 11.5 & 5.72 & 5.2 \\
\hline & Aver. & 165.1 & 2.261 & 13.7 & 5.42 & 5.0 \\
\hline \multirow[t]{4}{*}{2} & 1 & 98.3 & 1.669 & 9.7 & 6.71 & 6.1 \\
\hline & 2 & 75.5 & 1.926 & 11.2 & 4.29 & 3.9 \\
\hline & 3 & 108.2 & 1.857 & 10.8 & 5.28 & 4.8 \\
\hline & Aver. & 94.0 & 1.817 & 10.5 & 5.42 & 4.9 \\
\hline \multirow[t]{4}{*}{$\mathbf{8}$} & 1 & 117.0 & 1.144 & 7.2 & 4.62 & 4.2 \\
\hline & 2 & 110.5 & 1.033 & 6.5 & 3.96 & 3.6 \\
\hline & 3 & 86.5 & 1.319 & 8.3 & 4.84 & 4.4 \\
\hline & Aver. & 104.6 & 1.132 & 7.3 & 4.47 & 4.06 \\
\hline
\end{tabular}

In our series of casès of pernicious anemia the bulk of feces was very much increased, from $75.5 \mathrm{gm}$. to $175.5 \mathrm{gm}$. It will be seen that the average daily excretion of dry feces in the three cases was $165.1,114.0$ and $104.6 \mathrm{gm}$., respectively, an increase of from 100 to 200 per cent. as compared with the normal figures of Schmidt. The nitrogen elimination was also much increased in the first and second cases, being an evidence of some deficiency of protein absorption. The average excretion of nitrogen in the feces in the three cases was 13.7, 10.5 and 7.3 per cent., respectively. The fecal fat does not seem to vary much from the normal, the average figures for the three cases being 5.0, 4.9 and 4.06 per cent., respectively.

Perhaps as index of intestinal putrefaction attention may be paid to the urinary sulphur partition. It is known that in cases of intestinal stasis, etc., where the flora of the intestines are abnormal, there is an increased production of aryl compounds which are conjugated in the liver with sulphuric and glycuronic acids, and are excreted in the urine. Normally, the ethereal sulphates form approximately 10 per cent. of the total urinary sulphur. We found, as shown in Table 5, that in the first two cases there was a marked increase in the percentage of ethereal sulphates eliminated, whereas in Case 3, the increase is only slight. To our mind this is a distinct evidence of some putrefactive change going on in the body. We are aware of the theory that a certain portion of the ethereal sulphates is of endogenous origin. Our experience has, however, led us to the conclusion that when marked quantities of ethereal sulphates are 
excreted in the urine, presumptive evidence is present of intestinal putrefaction.

It will be noticed that the neutral sulphur fraction is also abnormally high, especially in Case 3 , an evidence of body suboxidation.

Table 5.-Urinary Sulphur Partírion *

\begin{tabular}{|c|c|c|c|c|c|c|c|c|c|}
\hline \multirow[b]{2}{*}{ Case } & \multirow[b]{2}{*}{ Day } & \multirow{2}{*}{$\begin{array}{l}\text { Volume } \\
\text { Urine, } \\
\text { C.c. }\end{array}$} & \multirow{2}{*}{$\begin{array}{c}\text { Total S, } \\
\mathbf{G m} .\end{array}$} & \multicolumn{2}{|c|}{ Inorganic $\mathrm{SO}_{4}$} & \multicolumn{2}{|c|}{ Ethereal SO, } & \multicolumn{2}{|c|}{ Neutral s } \\
\hline & & & & $\mathrm{Gm}$ & $\begin{array}{l}\text { Per } \\
\text { Cent. }\end{array}$ & Gm. & $\begin{array}{l}\text { Per } \\
\text { Cent. }\end{array}$ & Gm. & $\begin{array}{c}\text { Per } \\
\text { Cent. }\end{array}$ \\
\hline \multirow[t]{2}{*}{1} & $A \uparrow$ & 1,470 & 1.892 & 1.1162 & 59 & 0.4351 & 23 & 0.3407 & 18 \\
\hline & Bt & 1,215 & 1.536 & 0.8448 & 55 & 0.3993 & 26 & 0.2919 & 19 \\
\hline \multirow[t]{2}{*}{2} & $A$ & 1,625 & 1.074 & 0.5155 & 48 & 0.3014 & 29 & 0.2571 & 23 \\
\hline & B & 1,780 & 1.139 & 0.6150 & 54 & 0.3075 & 27 & 0.2165 & 19 \\
\hline \multirow[t]{2}{*}{3} & $\mathbf{A}$ & 950 & 0.935 & 0.5797 & 62 & 0.1496 & 16 & 0.2057 & 22 \\
\hline & B & 1,075 & 1.208 & 0.7006 & 58 & 0.1691 & 14 & 0.3383 & 28 \\
\hline
\end{tabular}

* The total sulphur was determined by Benedict s method, and the inorganic and ethereal sulphates by the method of Folin.

$t$ The days were not successive.

Function of the Pancreas.-An Einhorn duodenal tube was passed on each of the patients and allowed to remain in the patient over night. In the morning the duodenal contents were removed and analyzed. We were successful in obtaining bile stained duodenal contents in each instance.

It was found that the pancreatic enzymes were present in abundance. Protease, amylase, and lipase were found in normal quantities. No blood was found in any of the specimens. The methods used were, that of Gross for trypsin, that of Wohlgemuth for amylopsin, and the milk-litmus test for lipase.

In this connection it may be stated that the result of the SchmidtStrassburger test may be taken as evidence of the nonexistence of any pancreatic deficiency.

The stools obtained after the Schmidt-Strassburger diet were examined for the pancreatic enzymes and for blood, besides the usual examination for parasites, food particles, etc.

The pancreatic enzymes were present in abundance--trypsin, amylopsin and steapsin. No blood was found. No ova or parasites were found. Many meat fibers were, however, noticed. No free fat was observed.

The mucus in the stools varied. In one case the mucus was in abundance (Case 1); the other cases were normal. 
The blood and the urine were examined for amylase, as suggested by Wohlgemuth, and by Wohlgemuth and Noguchi, as a test for pancreatic insufficiency. We can only report negative results.

The pancreas seems to be functionating entirely normally, as evidenced by the tests enumerated.

Study of the Liver Function.-Bauer's galactose test and Strauss' levulose test were applied in two of the cases, with results that were negative in both instances.

Bauer's galactose test is performed as follows:

Thirty gm. of galactose are administered to the patient in the morning, and the urine collected for the next five or six hours. The presence or absence of galactose in the urine is determined by the Fehling test. The levulose test is applied as follows: One hundred gm. of levulose are administered in the morning, and the urine voided during the following five or six hours, tested by the Fehling and Seliwanoff tests for the presence or absence of levulose.

Sulpho-Conjugation Test. ${ }^{7}$-It was demonstrated by Baumann and others that the toxic carbocyclic radicals split off from the proteins by the growth of intestinal bacteria are conjugated in the liver with sulphuric acid and thus detoxicated. It is also known that a portion of these aryl compounds are detoxicated by conjugation with glycuronic acid.

It is obvious that in testing for the functional capacity of the liver it is essential not only to test the glycogenic, ureogenic, biligenic, etc., functions, but also to examine the detoxicating power of the hepatic tissue in order to ascertain the complete working power of the gland. This is done in the following manner:

The patient receives a dose of castor oil to evacuate his bowels. $\mathrm{He}$ is then kept on a known diet for two days, during which time the urine is collected, preserved and analyzed for total sulphur and ethereal sulphates. On the third day the patient receives a capsule containing $0.5 \mathrm{gm}$. thymol. The urine is collected for the next two days, preserved, and again analyzed for total sulphur and for ethereal sulphates.

If all the thymol were absorbed, and if all the thymol were conjugated with sulphuric acid and none with glycuronic acid, the $0.5 \mathrm{gm}$. thymol would be excreted as $0.766 \mathrm{gm}$. of thymol sulphuric acid. This would cause a marked increase in the percentage of ethereal sulphates in the urine. If the detoxicating power of the liver were below par, the thymol would not be conjugated, and the percentage of ethereal sulphates would be only slightly different from what it had been on the first two days--before the thymol administration.

We have found that this detoxicating function of the liver usually runs parallel with the other functional derangements of this organ.

7. Kahn, M.: Am. J. M. Sc. 155:668, 1918. 
In some cases; however, the conjugating power of the gland is markedly reduced, whereas the other functions do not show any disturbances as determined by the methods at our disposal. In still other cases the sulpho-conjugation is entirely normal (as determined by the test here described), while the other tests show a reduction of hepatic functional capacity.

It will be seen from the results charted in Table 6 that there seems to be a deficiency in the detoxication function of the liver. While it is seen from the sulphur partition (Table 5) that the liver conjugates an increased amount of aromatic radicals as evidenced by the ethereal sulphate output, still the administration of an additional aryl compound, thymol, does not seem to call forth the proper detoxicating influence of the liver in sufficient force.

Table 6.--Silpho-Conjugation Test of Hepatic Function

\begin{tabular}{c|c|c|c|c|c|c}
\hline \hline \multirow{2}{*}{ Case } & \multicolumn{2}{|c|}{ Total Sulphur, Gm. } & \multicolumn{2}{c|}{$\begin{array}{c}\text { Ethereal Sulphate } \\
\text { Sulphur, } \\
\text { Gm. }\end{array}$} & $\begin{array}{c}\text { Ethereal Sulphate } \\
\text { Sulphur, per Cent. of } \\
\text { Total Sulphur }\end{array}$ \\
\cline { 2 - 7 } & Before* & After & Before & After & Before & After \\
\hline $\mathbf{X}+$ & 2.0375 & 2.1295 & 0.2893 & 0.5646 & 14.2 & 26.8 \\
$\mathbf{1}$ & 1.536 & 1.6205 & 0.3993 & 0.5055 & 26.0 & 31.2 \\
2 & 1.139 & 1.0974 & 0.3075 & 0.3237 & 27.0 & 29.5 \\
3 & 1.208 & 1.1522 & 0.1691 & 0.2154 & 14.0 & 18.7 \\
\hline
\end{tabular}

* Before the administration of thymol, and after.

+ 'This was a normal individual.

Study of the Bile Pigments.-As Squier ${ }^{1}$ says, where active erythrocyte destruction is taking place, it is natural to expect that the limit must be approached above which the liver can no longer dispose of the liberated pigment. That such actually is the case has been shown by Sellards and Minot. They found that, compared with norma1, less hemoglobin is required to produce hemoglobinuria in patients suffering from pernicious anemia. The amount of hemoglobin necessary to induce hemoglobinuria bears no relation to the red cell count, but is in direct proportion to the amount of blood destruction taking place. This last, providing complicating factors are absent, is directly proportional to the excretion of urobilin in the intestine. Eppinger found that the normal urobilinogen excretion was 0.12 to $0.15 \mathrm{gm}$. per day. Schneider ${ }^{7}$ estimated the amount of hemolysis by examination of the duodenal contents and found in pernicious anemia, excessive excretion of bile pigments, or pleochromie, and urobilinocholia. Pleochromie is an expression of immediate hemolysis, and which, in pernicious anemia, whether in crisis or remission, is a constant finding. Urobilinocholia indicates a heaping 
up of pigment in the portal. system and varies directly as the portal system is surcharged or becomes relatively empty of the excess of pigment. Schneider ${ }^{8}$ points out that in secondary anemia no pleochromie or urobilinocholia is present (Squier ${ }^{1}$ ).

We followed Schneider's technic in detail. The duodenal contents were collected and examined for the pigments as follows:

To determine bilirubin: To 10 c.c. of duodenal contents are added 10 c.c. of an alkaline solution of calcium chlorid. After vigorous shaking this is filtered. The precipitate is dissolved under gentle heat in 10 c.c. of acid alcohol and the resulting green solution concentrated to a given volume. By colorimetric comparison with a standard green solution, the quantity is indicated as,+++ , or +++ .

To determine urobilin and urobilinogen: To 10 c.c. of duodenal contents are added 10 c.c. of Schlessinger's solution, the whole thoroughly shaken and allowed to filter. The filtrate should be slightly alkaline; if not, a drop or two of a weak ammonia solution are added. The filtrate will in the presence of urobilin show a more or less pronounced green opalescence. To 10 c.c. of this filtrate are added 1 c.c. of Ehrlich's benzaldehyd solution. In the presence of urobilinogen a red color will develop. This is allowed to stand in a dark place for fifteen minutes, and is then examined by the spectroscope (Schneider).

TABle 7.-Biliary Pigments

\begin{tabular}{|c|c|c|c|c|c|c|}
\hline \multirow{2}{*}{ Cases } & \multicolumn{3}{|c|}{ Duodenal Contents } & \multicolumn{2}{|c|}{ Urine } & \multirow{2}{*}{$\frac{\text { Feces }}{\text { Urobilinogen }}$} \\
\hline & Bilirubin & Urobilin & Urobilinogen & Bllirubin & Urobllin & \\
\hline $\begin{array}{c}\text { Schneider's } \\
1\end{array}$ & +++ & $+t+$ & $+t+$ & 0 & + & \\
\hline 2 & +++ & 2,000 & 1,800 & & & \\
\hline 3 & +++ & 4,000 & 2,800 & 0 & 1,000 & \\
\hline 4 & +++ & 2,000 & 1,200 & 0 & 1,000 & +++ \\
\hline $5^{*}$ & +++ & 2,300 & 2,500 & $\cdots$ & 1,000 & $++t$ \\
\hline$\underset{1}{\text { Authors' }}$ & +++ & +++ & +++ & 0 & + & +++ \\
\hline 2 & +++ & +++ & +++ & 0 & + & +++ \\
\hline 3 & +++ & +++ & +++ & 0 & + & $\cdot+++$ \\
\hline
\end{tabular}

* Urobilinogen in urine 100.

We applied these tests qualitatively and confirm Schneider's results (Table 8).

An examination of the urinary nitrogen partition was made in each case. In general the results were negative except that the oxyproteic acid nitregen fraction was increased to twice the normal, a condition frequently met with in carcinoma and in syphilis. The results will be found in Table 8 .

8. Schneider: Arch. Int. Med. 17:32, 1916. 15 c.c.

9. Para-dimethylaminobenzaldehyd, 2 gm.; acid hydrochloric, 15 c.c.; water, 
TABle 8.-Urinary Nitrogen Partition

\begin{tabular}{c|c|c|c|c|c|c|c|c|c}
\hline \hline Case & $\begin{array}{c}\text { Volume, } \\
\text { C.c. }\end{array}$ & $\begin{array}{c}\text { Total N. } \\
\text { Gm. }\end{array}$ & $\begin{array}{c}\text { Urea } \\
\text { Ne, } \\
\text { per } \\
\text { Cent. }\end{array}$ & $\begin{array}{c}\text { Am- } \\
\text { monia N, } \\
\text { per } \\
\text { Oent. }\end{array}$ & $\begin{array}{c}\text { Uric } \\
\text { Acid N, } \\
\text { per } \\
\text { Cent. }\end{array}$ & $\begin{array}{c}\text { Purin } \\
\text { N, } \\
\text { per } \\
\text { Cent. }\end{array}$ & $\begin{array}{c}\text { Creat- } \\
\text { inin N, } \\
\text { per } \\
\text { Cent. }\end{array}$ & $\begin{array}{c}\text { Oxy- } \\
\text { Protein } \\
\text { N, } \\
\text { per } \\
\text { Cent. }\end{array}$ & $\begin{array}{c}\text { Rest } \\
\text { N, } \\
\text { per } \\
\text { Cent. }\end{array}$ \\
\hline 1 & 1,470 & 16.52 & 79.3 & 4.2 & 2.7 & 2.1 & 2.8 & 3.9 & 5.0 \\
2 & 1,625 & 9.35 & 81.6 & 3.7 & 3.1 & 2.7 & 3.1 & 4.2 & 1.6 \\
$\mathbf{3}$ & 950 & 12.17 & 82.5 & 3.4 & 2.9 & 2.5 & 2.6 & 5.3 & 0.8 \\
\hline
\end{tabular}

Study of Kidney Function. - The phenolsulphonephthalein test was tried twice on each case. The results, in general, did not indicate any deviation from the normal. It is always advisable, when one obtains a low.phenolsulphonephthalein output to repeat the test for confirmation; for, we have found in numerous instances that a low output may only indicate a faulty technic rather than a poor renal function. Table 9 shows the results obtained in the three cases.

TABLE 9.-Phenolsulphonephthalein OUtPlt

\begin{tabular}{c|c|c|c|c}
\hline Case & Test Number & $\begin{array}{c}\text { Per Cent. } \\
\text { First Hour }\end{array}$ & $\begin{array}{c}\text { Per Cent. } \\
\text { Second Hour }\end{array}$ & $\begin{array}{c}\text { Per Cent. } \\
\text { Total }\end{array}$ \\
\hline 1 & 1 & 25 & 15 & 40 \\
2 & 2 & 48 & 40 & 88 \\
& 1 & 37 & 30 & 67 \\
3 & 2 & 35 & 34 & 69 \\
& 1 & 42 & 30 & 72 \\
& 2 & 40 & 28 & 68 \\
\hline
\end{tabular}

Examination of the blood plasma for several nitrogen fractions (Table 1) showed that there was no increase in the nonprotein nitrogen, urea nitrogen, or uric acid. This is a good evidence of normal kidney function.

The only nitrogen fraction increased in the blood, especially in Cases 2 and 3, is the creatinin, due more to the destructive process present in the body rather than to any failure of the kidney to eliminate this substance. It is remarkable how often syphilitic patients yield a high creatinin figure in the blood.

There was acidosis, to a certain degree, present in all of the three cases of pernicious anemia. The carbon dioxid combining power of the plasma was much reduced, as determined by the Van Slyke method. The $\mathrm{H}$ ion concentration is increased, and the carbon dioxid of the alveolar air was $4.4,4.7$, and 4.6 in the three cases, respectively. 


\section{HISTORY OF THE CASES}

CASE 1.-Jewish woman, 45 years old, married; no children; four miscarriages; husband well. A Wassermann ${ }^{20}$ was performed on her and twice found positive weakly. When she came to the hospital, she had a red blood count of 720,000 , hemoglobin 35 per cent., color index 2 , white blood count 6,600 , neutrophils 53 per cent., eosinophils 1 per cent., large mononuclears 2 per cent., lymphocytes 44 per cent. There was marked anisocytosis and poikilocytosis. The coagulation time was 12.5 minutes; blood platelets 150,000 . She remained in the hospital for three months, being transfused a number of times by the citrate method. Salvarsan had no effect. During one of the remissions she left the hospital.

CaSe 2.-Married salesman; has one child; ill eight months; denies syphilis; had gonorrhea; Wassermann doubtful. Blood: red blood count 1,200,000, hemoglobin 45 per cent., color index 1.8; marked anisocytosis and poikilocytosis; normoblasts present; platelets 185,000 ; coagulation time 11 minutes. ${ }^{11}$ The patient was transfused several times, but did not rally, and died. No necropsy.

CASE 3.-Married woman, aged 42; two children; ill one year. Blood: Wassermann negative; red blood count $1,400,000$, hemoglobin 42 per cent., color index 1.3 , blood platelets 210,000 , coagulation time 13.5 minutes; white blood count 7,200, polynuclears 62 per cent.; many normoblasts. The patient was transfused several times, but left the hospital during a remission.

\section{CONCLUSIONS}

1. A study of the chemistry of three cases of pernicious anemia is presented.

2. The blood analysis shows a lessened specific gravity of the serum, reduction of the protein content, an increase in the ash and lime content, and a normal fat, cholesterol and glucose percentage.

3. There is complete anacidity present in the stomach, an increased residuum, and absence of pepsin, resembling the gastric picture present in cases of carcinoma ventriculi.

4. The Wolff-Junghans test is negative.

5. Intestinal digestion is disturbed. The fecal bulk is much increased, and the nitrogen lost in the feces above normal. The fat in the feces is normal.

6. Intestinal putrefaction, as evidenced by-increased ethereal sulphate output, is present. There is a state of suboxidation - the neutral sulphur fraction is increased.

7. The pancreas functionates normally, as evidenced by enzyme examination of duodenal contents and feces.

10. It has been the experience of one of us (Kahn) that pernicious anemia patients very frequently have a positive Wassermann test.

11. The coagulation time was determined by collecting a few drops of blood from an arm vein by means of a needle into a flat bottom test tube. By gently tilting the tube occasionally, one can determine the coagulation time very exactly. 
8. There is a deficiency in the hepatic detoxication function as shown by the sulphoconjugation test. The glycogenic and ureogenic functions of the liver are normal.

9. The excessive hemolysis of pernicious anemia is attended by both a pleochromie and a urobilinocholie. In this regard we corroborate Schneider's experiments.

10. There is an increased elimination of oxyproteic acid nitrogen in the urine in cases of pernicious anemia; the other urinary nitrogen fractions being normal.

11. The renal function is normal as evidenced by the phenolsulphonephthalein test, and the blood nitrogen partition.

12. The creatinin in the blood is increased.

13. Acidosis was present in the cases examined, as determined by the carbon dioxid combining power of the blood plasma, the $\mathrm{H}$ ion concentration of the blood, and the carbon dioxid of the alveolar air.

The following references may also be consulted: .

Addis: Archives Int. Med. 15:413, 1915.

Abderhalden: Ztschr. f. Biol. 21:483, 1900.

Asher and Grossenbacher: Biochem. Ztschr. 17:78, 1909.

Austin and Pearce: J. Exper. Med. 20:122, 1914.

Biedl and Kraus: Ztschr. f. Immunitätsforsch. 15:447, 1912.

Hurwitz: Bull. Johns Hopkins Hosp. 26:235, 1915. 